\title{
CONFERÊNCIAS PROMOVIDAS PELO INSTITUTO UNIVERSITÁRIO DE DESENVOLVIMENTO E PROMOÇÃO SOCIAL
}

No âmbito das suas actividades de extensão cultural, o I.U.D.P.S. promoveu diversas conferências no decurso de 1995.

No dia 27 de Abril, o Prof. José Maria Amado Mendes proferiu uma conferência intitulada "Oliveira Martins e a indústria".

Após a conferência, foi lançado o volume 3 (1994) da revista GESTÃO E DESENVOLVIMENTO.

A 19 de Maio, o Prof. Luís Valadares Tavares, do Instituto Superior Técnico e da Universidade Católica Portuguesa, abordou a seguinte temática: "O planeamento estratégico".

No dia 1 de Junho, o Prof. Luís Reis Torgal, da Faculdade de Letras da Universidade de Coimbra, proferiu uma conferência, acompanhada da projecção de um videograma, intitulada "Os doutoramentos solenes na Universidade de Coimbra".

Todas as conferências se realizaram no Auditório Engenheiro Engrácia Carrilho, tendo às mesmas assistido professores e alunos do Instituto Universitário de Desenvolvimento e Promoção Social.

\section{PARA UMA AVALIAÇÃO GLOBAL DO ENCONTRO GESTÃO EM ANÁLISE}

O Instituto Universitário de Desenvolvimento e Promoção Social (I.U.D.P.S.) da Universidade Católica Portuguesa (Pólo de Viseu do Centro Regional das Beiras) ao promover, nos dias 23 e 24 de Novembro de 1995, o Encontro A Gestão em Análise teve em vista, fundamentalmente, os seguintes objectivos:

$1 .^{\circ}$ Comemorar, através de uma iniciativa científica e formativa, $010 .^{\circ}$ aniversário da licenciatura em Gestão e Desenvolvimento Social; 


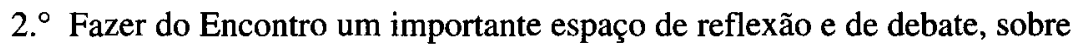
a problemática da gestão, nas suas múltiplas vertentes, capaz de mobilizar, em torno do mesmo objectivo, com o apoio insubstituível de conferencistas de reconhecido mérito, docentes, alunos, empresários, quadros superiores das organizações lucrativas e não lucrativas, bem como todos os demais interessados na problemática em causa.

3. Contribuir com esta iniciativa para uma mais fecunda e efectiva relação entre a Universidade e os diferentes actores sociais (numa posição de sincera partilha de experiências e de saberes), tornando assim real uma das mais importantes exigências das instituições de ensino superior.

Pode dizer-se, sem qualquer ponta de auto-elogio, que, no essencial, os objectivos definidos pelo I.U.D.P.S. e pela Comissão Organizadora do Encontro A Gestão em Análise foram conseguidos. Para que isto fosse possível, é justo salientar a qualidade das conferências aqui produzidas - sobre temas tão importantes e variados como: A Gestão Universitária; A Internacionalização das Empresas: o desafio da sobrevivência; A Gestão Industrial; A gestão Comercial; A Gestão Política Administrativa; A Gestão Empresarial; A Gestão Financeira -, bem como a participação activa nos debates de grande parte dos mais de trezentos inscritos neste evento. Entre estes, destaque-se a forte adesão dos actuais e antigos alunos da licenciatura em Gestão e Desenvolvimento Social, para além naturalmente da recepção que este encontro teve junto de docentes e quadros superiores de empresas.

Cumpre aqui salientar, também, a boa receptividade que o Encontro de Gestão teve junto dos órgãos de comunicação social, com maior incidência na imprensa regional falada e escrita (estiveram representados 18 órgãos de informação), donde sem excepção saíram rasgados elogios à iniciativa.

Ainda assim, qualquer balanço sobre um acontecimento deste género ficaria incompleto se dele não se retirassem algumas ilações. Entre muitas possíveis, são de sublinhar as seguintes:

a) Ainda que poucos disso duvidassem, este Encontro sobre a problemática da gestão mostrou, de uma forma inquestionável, que é por via de iniciativas deste género que a Universidade melhor pode cumprir um dos seus objectivos mais importantes: contribuir activa e positivamente para o desenvolvimento da região onde se insere;

b) Decorrente disso, parece-nos claro que eventos semelhantes se devem repetir com uma periodicidade regular (anual ou de dois em dois anos), para que, deste modo, sobretudo a região onde se insere a Universidade se habitue a ver nesta, não algo de distante, mas um importante espaço de reflexão e de discussão cada vez mais importantes. 
Nenhuma Comissão promotora de uma iniciativa poderá alguma vez sentir-se absolutamente satisfeita com os resultados alcançados. Assim, ainda que o saldo global tivesse sido significativamente positivo, há que arranjar no futuro estratégias mais eficazes, para uma maior mobilização dos empresários da região para este tipo de iniciativas.

António Rafael Amaro

\section{ESTÁGIOS NO ANO LECTIVO 1995/96}

Dá-se aqui continuidade ao já referido nos n. ${ }^{\text {s }} 2$ (1993, p. 143-148) e 3 ( 1994 , p. 195-197) desta revista. O esforço de gestão do estágio integrado na Licenciatura, levado a cabo pelo I.U.D.P.S., tem sido conseguido, graças à colaboração de todos os docentes, ao corpo de supervisores e aos responsáveis pela gestão das organizações económicas e sociais. Estes não só permitiram a integração do(s) aluno(s) como também desempenharam um papel fundamental na orientação dos seus trabalhos, em articulação com o supervisor de cada estagiário.

No ano lectivo de 1995/96 realizaram o seu estágio 83 alunos do 5. ${ }^{\circ}$ ano da Licenciatura em Gestão e Desenvolvimento Social.

Para o efeito conta-se com a colaboração de 71 organizações económicas e sociais, tendo sido, no entanto, disponibilizados 109 lugares de estágio.

\section{Gráfico I}

\section{Centros de Estágio no Ano Lectivo de 1995/96}

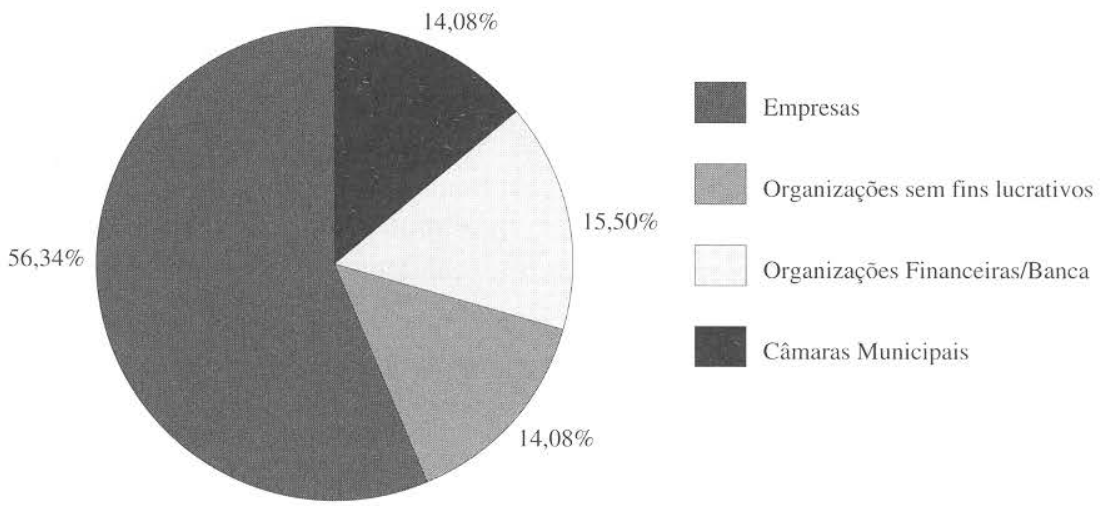

Fonte: Dados do Processo de Estágios do Ano Lectivo de 1995/96 